\title{
Promosi dan Pemeriksaan Kesehatan pada Penderita Diabetes Melitus
}

\author{
Novita Dewi ${ }^{1}$, Supriadi ${ }^{2}$, Errict Indra Cita $^{3}$ \\ 1,2,3 Fakultas ilmu Kesehatan, Universitas Tribhuwana Tunggadewi \\ Email: novita2unitri@gmail.com
}

Submitted : 28/09/2021

Accepted: 16/10/2021

Published: 19/11/2021

\begin{abstract}
Corona virus infection, also known as COVID-19 (Corona Virus Disease 2019), is booming, spreading rapidly, resulting in death. Prevention of the spread of the virus by implementing health protocols carried out by all aspects of society, especially in hospitals, where patients are cared for and the families who look after them, are very vulnerable to contracting COVID-19, so education is needed for the patient's family about the health protocol. The implementation of health protocols can be improved through education on the implementation of health protocols carried out in hospitals. The purpose of community service is to provide education to the families of patients who are hospitalized. The method used is the CBR (Community Based Research) approach, by educating the patient's family directly/offline one by one by implementing health protocols; wear a mask, keep your distance, avoid crowds. The time for the education implementation on December 28, 2020, was carried out on the patient's family with a duration of 20 minutes. Community service is carried out with a community service team consisting of professional students for the 2020/2021 academic year. The media used in the form of leaflets. The results of community service in the form of increased knowledge and changes in the implementation of health protocols. Knowledge is obtained, all of the patient's family understands the material for implementing the health protocol that has been given. Recommendations for community service in the future use interactive learning media so that the education provided can be understood properly.
\end{abstract}

Keywords: community service for the prevention of covid-19, health protocol education,

\begin{abstract}
Abstrak
Infeksi virus Corona disebut juga sebagai COVID-19 (Corona Virus Disease 2019), sedang booming, menyebar secara cepat, berakibat kematian. Pencegahan penyebaran virus tersebut dengan menerapkan protocol kesehatan yang dilakukan oleh seluruh aspek masyarakat, terutama di rumah sakit, tempat pasien dirawat dan keluarga yang menjaganya, sangat rentan tertular covid-19, maka diperlukan edukasi pada keluarga pasien mengenai protocol kesehatan. Penerapan protocol kesehatan dapat ditingkatkan dengan melalui edukasi penerapan protocol kesehatan yang dilakukan di rumah sakit. Tujuan pengabdian masyarakat memberikan edukasi pada keluarga pasien yang dirawat dirumah sakit. Metode yang digunakan pendekatan CBR (Comumunity Based Research), dengan melakukan edukasi kepada keluarga pasien secara langsung/ offline satu persatu dengan menerapkan protocol kesehatan ; menggunakan masker, menjaga jarak, menghindari kerumunan. Waktu pelaksaan edukasi 28 Desember 2020, dilakukan pada keluarga pasien dengan durasi 20 menit. Pengabdian masyarakat dilakukan bersama tim pengabdian masyarakat yang terdiri dari mahasiswa profesi ners TA 2020/2021. Media yang digunakan berupa leaflet. Hasil dari pengabdian masyarakat berupa peningkatan pengetahuan dan perubaahan tinadakan penerapan protocol kesehatan. Pengetahuan didapatkan seluruhnya keluarga pasien memahami tentang materi penerapan protocol kesehatan yang telah diberikan. Rekomendasi pengabdian masyarakat kedepan menggunakan media pembelajaran yang interaktif sehingga edukasi yang diberikan dapat dipahami dengan baik.
\end{abstract}

Kata kunci: edukasi protocol kesehatan, pengabdian masyarakat pencegahan covid-19. 


\section{PENDAHULUAN}

Infeksi virus Corona disebut juga sebagai COVID-19 (Corona Virus Disease 2019), booming di Wuhan sejak akhir Desember 2019 (Dennison Himmelfarb \& Baptiste, 2020). Strain coronavirus disebut juga sindrom pernapasan akut coronavirus 2 (SARS-CoV-2), dikenal juga 2019-nCoV. Infeksi yang disebabkan oleh virus ini dikenal sebagai coronavirus disease-2019 (COVID-19) (World Health Organization, 2020.) 2019-nCoV adalah beta-coronavirus, seperti juga virus yang menyebabkan sindrom pernapasan akut parah (SARS) dan sindrom pernapasan Timur Tengah (MERS) ( World Health Organization, 2020; Centers for Disease Control and Prevention.2020). Namun, gambaran klinis COVID-19 yang komprehensif masih belum sepenuhnya jelas (Centers for Disease Control and Prevention., 2020). Kasus COVID-19 meningkat jumlah kasus dan meluasnya penyebaran geografis meningkatkan kekhawatiran besar tentang lintasan wabah di masa depan. Akibatnya, epidemi COVID-19 telah menyebabkan penerapan langkah-langkah kesehatan masyarakat yang luar biasa untuk mengurangi penyebaran virus lebih lanjut (Centers for Disease Control and Prevention.,2020; Covid, 19 2020)

Virus ini menular dengan sangat cepat dan telah menyebar ke hampir semua negara, termasuk Indonesia, hanya dalam waktu beberapa bulan. Virus Corona yang menyebabkan COVID-19 bisa menyerang siapa saja. Menurut data yang dirilis Gugus Tugas Percepatan Penanganan COVID-19 Republik Indonesia, jumlah kasus terkonfirmasi positif hingga 24 Juni 2020 adalah 47.896 orang dengan jumlah kematian 2.535 orang. Tingkat kematian (case fatality rate) akibat COVID-19 adalah sekitar 5,4\%. Jika dilihat dari persentase angka kematian yang di bagi menurut golongan usia, maka lansia memiliki persentase tingkat kematian yang lebih tinggi dibandingkan golongan usia lainnya.
Sedangkan berdasarkan jenis kelamin, $60,6 \%$ penderita yang meninggal akibat COVID-19 adalah laki-laki dan 39,4\% sisanya adalah perempuan. Perlu adanya pencegahan untuk menghindari terjangkitnya dan penyebaran virus COVID-19.

Pencegahan penyebaran dilakukan secara terpusat maupun individu. Pemerintah Indonesia telah menetapkan langkah-langkah dan upaya pencegahan pandemic covid-19 salah satunya adalah dengan mensosialisasikan gerakan socialdistancing atau yang juga banyak dikenal sebagai physical distancing, konsep ini menjelaskan bahwa dapat mengurangi atau memutus mata rantai penularan atau penyebar infeksi covid-19, dalam upaya ini seseorang harus menjaga jarak dengan orang lain minimal 2 meter, dan tidak melakukan kontak langsung dengan orang lain, menghindari kerumunan dan pertemuan masal, ditambahkan dengan perilaku peningkatan imunitas (Amalia \& Hiola, 2020; Ausrianti \& Andayani, 2020). Himbauan untuk mengenakan masker dan memperhatikan protocol kesehatan saat beraktivitas diluar rumah masih diabaikan. Masih ditemukan banyak pengunjung RS yang tidak mengunakan masker secara benar dan tidak mematuhi protokol kesehatan. Disituasi dan kondisi saat ini, kesadaran seluruh masyarakat untuk patuh dan taat dalam menjalankan protocol kesehatan memiliki peran yang signifikan, sehingga perlu ditekankan kepada para pengunjung RS untuk mematuhi protocol kesehatan covid-19 untuk mencegah dan memutuskan mata rantai penyebaran covid -19 di RS, Itulah sebabnya, para ahli pun terus mencari solusi terbaik untuk mengatasi masalah ini. Salah satunya adalah dengan edukasi protocol kesehatan di RS dimasa pandemi. Semua orang yang mempunyai kepentingan dan keperluan di RS, sebagai pasien maupun sebagai keluarga pasien, inilah yang menjadi tantangan karena datangnya keluarga dan 
orang-orang ke RS akan menyebabkan banyaknya perkumpulan. Hal ini menyebabkan banyaknya pengunjung Rs tidak mematuhi protokol kesehatan pada, para pengunjung rumah sakit sudah bisa mengerti tetang protokol kesehatan sehingga mudah untuk menyampaikan pendidikan kesehatan penerapan protokol kesehatan di RS. Berdasarkan fenomena tersebut, maka penulis tertarik untuk mengambil judul "Edukasi Penerapan Protokol Kesehatan di RS Dimasa pandemi”.

\section{TARGET DAN LUARAN}

Pengabdian masayarakat yang dilakukan diharapkan pasien dan keluarga mampu meningkatkan pengetahuan mereka tentang penerpaan protocol kesehatan di rumah sakit dimasa pandemic.

\section{METODE PELAKSANAAN}

Pengabdian masyarakat dilksanakan pada tanggal 28 Desember 2020, di Rumah sakit, dilakukan pada 25 audience pada rumah sakit tersebut. Metode digunakan dengan pendekatan CBR (Comumunity Based Research), megunjungi keluarga pasien satu persatu kemudian diberikan edukasi selama 20 menit, kemudian dilaksanakan metode simulasi penerapan protocol kesehatan selama di Rumah sakit. Meliputi cara mencuci tangan yang benar, penggunaan masker, social distanching 1-2 meter antar orang, session berikutnya diskusi, tanya jawab terkait materi dan seputarnya, kemudian pembagian leaflet kepada audience.

\section{HASIL DAN PEMBAHASAN}

Pelaksanaan pengabdian masyarakat dilakukan pada tanggal 23 Desember 2020 bertempat rumah sakit dengan dihadiri oleh 25 keluaga pasien yang sedang menunggu pasien di rumah sakit, keluarga pasien merasakan pelayanan prima dengan dengan diperhatikan oleh perawat dengan dilakukan edukasi privat, hal ini dilakukan untuk memaksimalkan edukasi, meskipun membutuhkan energi yang lebih karena mendatangi satu persatu audience. ditangani satu persatu oleh perawat yang sedang melaksanakan abdimas tersebut.

Kegiatan edukasi tentang protocol kesehatan berjalan dengan lancar dengan tetap menerapkan protocol kesehatan berupa pemakaian masker, menjaga jarak, menghindari kerumunan masa, dan dilakukan secara one by one. Ruangan yang digunakan menyesuaikan dengan tempat dimana keluarga merawat pasiennya. Sebagian dilakukan di ruang perawatan, poli, maupun ruang tunggu pasien.

Respon yang diberikan oleh masyarakat adalah ini didapatkan hasil responden memiliki pengetahuan yang lebih baik dari sebelumnya mengenai pentingnya penerapan protokol kesehatan di masa pandemik selama di rumah sakit memenuhi yaitu 4M: Memakai masker, mencuci tangan, menjaga jarak, menjauhi kerumunan. Tindakan pencegahan tersebut dilakukan dengan cara pemberian edukasi, penyuluhan yang dilakukan diberbagai kalangan masyarakat berupa penelitian dan pengabdian masyarakat (Fithriyani \& Yesni, 2021; Lestari \& Lita, 2021; Nurhana et al., 2021; Sudayasa et al., 2021).

Keberhasilan pembiasaan melakukan protocol kesehatan harus tetap dipertahankan bahkan harus ditingkatkan dengan menggunakan media pembelajaran yang lebih menarik, bahkan dalah hal pengobatan (Andian \& Saputra, 2021; F, 2021; Himawan et al., 2021) penyuluhan yang dilakukan pada sasaran masyarakat tentu akan berbeda dengan penggunaan media online. Penyuluhan yang dilakukan dimasyarakat dilakukan dengan offline, tetapi tetap menerapkan protocol kesehatan (Al Hakim et al., 2021; Yulianis et al., 2021). Berbeda dengan edukasi yang bersifat online; meliputi webinar, zoometing yang bias diunggah di youtube (Sudayasa et al., 2021) 


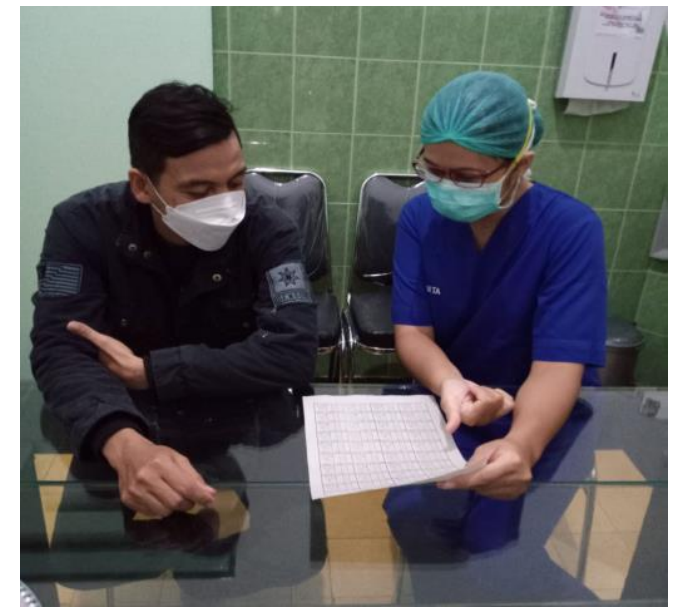

Gambar 1. Penerapan protokol kesehatan pada keluarga pasien di rumah sakit

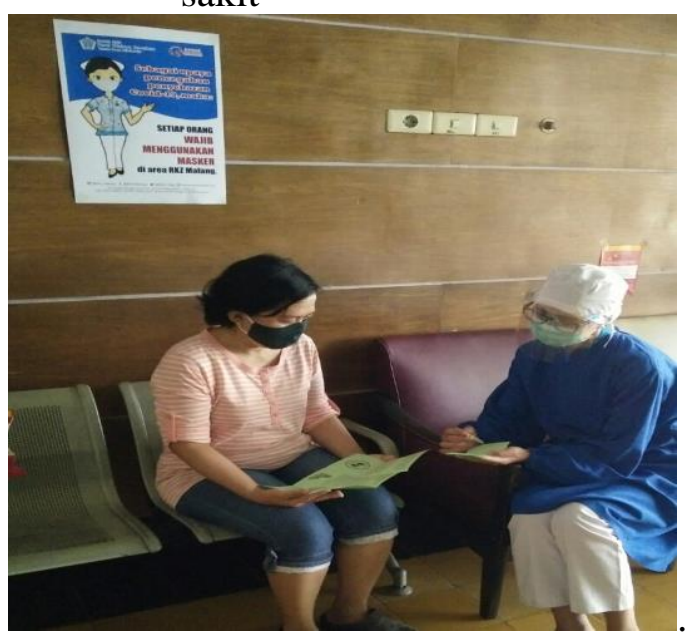

Gambar 2. Penerapan protokol kesehatan pada keluarga pasien di rumah sakit

\section{KESIMPULAN DAN SARAN}

\section{Kesimpulan}

Program studi pendidikan profesi ners telah melaksanakan kegiatan pengabdian masyarakat (penyuluhan kesehatan). Kegiatan ini dilakukan untuk menyampaikan pentingnya penerapan protokol kesehatan di masa pandemik yaitu dengan pencegahan 4M: memakai masker, mencuci tangga di air mengalir dan memakai sabun, menjaga jarak dan menjauhi kerumunan. Edukasi ini diharapkan audience dapat mengikuti protokol kesehatan sehingga angka penularan covid-19 semakin berkurang.

\section{Saran}

1. Diharapkan penerapan protokol kesehatan akan terus berlanjut di masa pandemik.

2. Dengan penerapan protocol kesehatan diharapakan dapat memutuskan rantai penyebaran covid-19.

\section{UCAPAN TERIMAKASIH}

Terima kasih sebanyak-banyaknya kami haturkan kepada prodi ners yang telah memberikan hibah penerbitan artikel pengabdian masyarakat, sehingga artikel ini dapat dipubiksikan. .

\section{DAFTAR PUSTAKA}

Al Hakim, L., Supeni, S., Khabibullah, M., \& Skenoma, Y. (2021). Pemberdayaan Masyarakat Desa Plesungan Melalui Penyuluhan Pembuatan Oleh-Oleh Makanan dan Cenderamata Khas Desa. Jurnal Abdimas PHB: Jurnal Pengabdian Masyarakat Progresif Humanis Brainstorming, 4(1), 53-61.

Amalia, L., \& Hiola, F. (2020). Analisis gejala klinis dan peningkatan kekebalan tubuh untuk mencegah penyakit covid-19. Jambura Journal of Health Sciences and Research, 2(2), 71-76.

Andian, N. P., \& Saputra, P. P. S. (2021). Edukasi Pencegahan Penularan Virus Corona Dan Pemberdayaan Masyarakat Memproduksi Jamu Kekebalan Tubuh Di Kelurahan Indro, Gresik. Abdimas Galuh, 3(1), 155162.

Ausrianti, R., \& Andayani, R. P. (2020). Promosi Kesehatan Jiwa Masyarakat Menghadapi Era New Normal. Jurnal Abdimas Saintika, 2(2), 97-101.

Centers for Disease Control and Prevention. (n.d.-a). Coronavirus symptoms and diagnosis.

https://www.cdc.gov/coronavirus/abou tsymptoms.html

Centers for Disease Control and Prevention. 
(n.d.-b). Sindrome Severe acute respiratory.

Covid, W. H. O. (19 C.E.). Weekly epidemiological update. World Health Organization.

Dennison Himmelfarb, C. R., \& Baptiste, D. (2020). Coronavirus Disease (COVID-19). Journal of Cardiovascular Nursing, 35(4), 318321.

https://doi.org/10.1097/jen.000000000 0000710

F, K. Ge. (2021). Pengaruh Edukasi Farmasis Terhadap Hasil Terapi Dan Kualitas Hidup Pasien Prolanis Diabetes Melitus Tipe 2. Syntax Literate: Jurnal Ilmiah Indonesia pISSN: 2541-0849 e-ISSN: 2548-1398 Vol. 6, No. 1, Januari 2021, 6(1).

Fithriyani, F., \& Yesni, M. (2021). Edukasi tentang Protokol Pencegahan Covid-19 kepada Masyarakat Kelurahan Lebak Bandung Kota Jambi. Jurnal Abdimas Kesehatan (JAK), 3(2), 174-177.

Himawan, F., Suparjo, S., \& Hudinoto, H. (2021). Edukasi Dan Sosialisasi Pencegahan Covid-19 Melalui Upaya Peningkatan Imunitas Tubuh Dengan Dzikir Dan Herbal Di Kelurahan Debong Kulon Tegal. JABI: Jurnal Abdimas Bhakti Indonesia, 2(1), 4350.
Lestari, R. F., \& Lita, L. (2021). Protokol Keluar dan Masuk Rumah Selama Pandemi Covid-19. Jurnal Abdimas Kesehatan (JAK), 3(2), 131-135.

Nurhana, S., Safitri, U. R., \& Setiawati, D. (2021). Edukasi penerapan protokol kesehatan di tpa an-nur, dukuh gading, ngargosari, ampel, boyolali. 2(09), 81-85.

Sudayasa, I. P., Haryati, H., Purnamasari, Y., Chintia, Y. F., Anwar, N. R., Permatasari, P., \& Pebriyanti, P. (2021). Peningkatan Pengetahuan Masyarakat dalam Penerapan Protokol Kesehatan melalui Edukasi Berbasis Media Online. PengabdianMu: Jurnal Ilmiah Pengabdian Kepada Masyarakat, 6(2), 175-183.

World Health Organization. (n.d.). Coronavirus. https://www.who.int/healthtopics/coronavirus.

Yulianis, Y., Wardana, A. K., Wati, D., Dila, I., Della F, N., Rosmawati, R., Suryani, S., Oktaviani, W., \& Hidayah, N. (2021). Penyuluhan tentang cara menjaga kesehatan di masa pandemi di Kelurahan Pakuan Baru Jambi. Jurnal Pengabdian Harapan Ibu (JPHI), 3(1), 39-46. 